\title{
THE IMPACTS OF BRAND EXPERIENCES ON BRAND LOVE, BRAND TRUST, AND BRAND LOYALTY: AN EMPIRICAL STUDY
}

\author{
Sharon Madeline ${ }^{1}$, Sabrina O. Sihombing ${ }^{2}$ \\ ${ }^{1,2}$ Universitas Pelita Harapan, Indonesia
}

\begin{abstract}
Previous studies that studied brand relationships tended to ignore the relationship between brand experience and brand loyalty and the role of brand love and brand trust. Therefore, the main objective of this study is to examine the effect of brand experience on brand loyalty through brand love and brand trust. For this study, questionnaires were distributed via personal and email, with 300 respondents aged between 18 and 50 using a purposive sampling method. Data were analyzed using structural equation modeling. The results found that brand experience has positive brand love and trust, brand love and brand trust have a positive effect on brand loyalty.
\end{abstract}

Keywords: brand experiences, brand love, brand loyalty, brand trust

\section{DAMPAK PENGALAMAN MEREK PADA CINTA MEREK, KEPERCAYAAN MEREK, DAN LOYALITAS MEREK: SEBUAH STUDI EMPIRIK}

\begin{abstract}
ABSTRAK
Studi sebelumnya yang mempelajari hubungan merek cenderung mengabaikan hubungan antara pengalaman merek dan loyalitas merek dan peran cinta merek dan kepercayaan merek. Oleh karena itu, tujuan utama dari penelitian ini adalah untuk menguji pengaruh pengalaman merek terhadap loyalitas merek melalui cinta merek dan kepercayaan merek. Untuk tujuan penelitian ini, kuesioner didistribusikan melalui pribadi dan email, dengan 300 responden berusia antara 18 dan 50 menggunakan metode purposive sampling. Data dianalisis menggunakan pemodelan persamaan struktural. Hasil menemukan bahwa pengalaman merek memiliki cinta dan kepercayaan merek yang positif, cinta merek dan kepercayaan merek memiliki efek positif terhadap loyalitas merek.
\end{abstract}

Kata-kata kunci: cinta merek, kepercayaan merek, loyalitas merek, pengalaman merek

Korespondensi: Dr. Sabrina O. Sihombing Universitas Pelita Harapan. UPH Tower Lippo Karawaci Tangerang 15811. Email: sabrina.sihombing@uph.edu.

Submitted: January 2019, Accepted: July 2019, Published: September 2019

ISSN: 1412 - 3681 (printed), ISSN: 2442 - 4617 (online), Website: http://journal.feb.unpad.ac.id/index.php/jbm 
Jurnal Bisnis dan Manajemen, Volume 20, No. 2, September 2019, p. 91-107

\section{INTRODUCTION}

Today, many companies create their products and services in order to deliver unforgettable experiences, especially when the importance of the customer experience increases, such as Samsung (Pine \& Gilmore, 2011; Schmitt \& Rogers, 2008). Many companies are adopting one of the essential marketing strategies, which is companies' customer acquisition. Companies that use this strategy focus on increasing consumers' brand experience. Samsung is one of the brands that are adapting the customer acquisition strategy. Samsung's goal is to familiarize people with their brand. One of the examples of Samsung's strategies to do so is by opening Samsung 837 in New York in 2016, which is a living lab and digital playground where people can experience their technology, services, and culture (Samsung, 2016; Greenwald, 2016). In addition, customer loyalty, as one of the main goals of many companies, is one source of the company's comparative advantage (Kandampully et al, 2015).

There are some marketing literature has examined the intermediate mechanisms between the relationships of these two constructs. However, not many of them discussed that brand loyalty that is affected by brand experience through brand love and brand trust. Table 1 shows some previous researches that studied some constructs that affect brand loyalty.
Table 1. Factors Affecting Brand Loyalty

\begin{tabular}{|c|c|c|c|}
\hline $\begin{array}{l}\text { Previous } \\
\text { Trust } \\
\text { Researchers }\end{array}$ & $\begin{array}{l}\text { Brand } \\
\text { Experience }\end{array}$ & $\begin{array}{l}\text { Brand Love } \\
\text { (Affective } \\
\text { Commitment) }\end{array}$ & Brand \\
\hline $\begin{array}{l}\text { Sahin et al } \\
\text { (2011) }\end{array}$ & $\mathrm{V}$ & & \\
\hline $\begin{array}{l}\text { Brakus et al } \\
\text { (2009) }\end{array}$ & V & & \\
\hline $\begin{array}{l}\text { Iglesias et al } \\
\text { (2011) }\end{array}$ & $\mathrm{V}$ & $\mathrm{V}$ & \\
\hline $\begin{array}{l}\text { Riasma et al } \\
(2018)\end{array}$ & $\mathrm{V}$ & & V \\
\hline $\begin{array}{l}\text { Lee et al } \\
(2009)\end{array}$ & & $\mathrm{V}$ & \\
\hline $\begin{array}{l}\text { Sung \& Kim } \\
\text { (2010) }\end{array}$ & & $\mathrm{V}$ & $\mathrm{V}$ \\
\hline $\begin{array}{l}\text { Horppu et al } \\
\text { (2008) }\end{array}$ & & & $\mathrm{V}$ \\
\hline $\begin{array}{l}\text { Ramaseshan } \\
\text { \& Stein } \\
\text { (2014) }\end{array}$ & $\mathrm{V}$ & & V \\
\hline $\begin{array}{l}\text { Singh et al } \\
\text { (2012) }\end{array}$ & & $\mathrm{V}$ & $\mathrm{V}$ \\
\hline $\begin{array}{l}\text { Kim \& Suh } \\
(2015)\end{array}$ & $\mathrm{V}$ & & \\
\hline
\end{tabular}

Source: Processed data (2018)

Therefore, the goal of this research is to fill the gap in the relationships between brand experience and brand loyalty through brand love and brand trust. This study is also presenting a model developed by Huang (2017), showing how far customers are developing their brand loyalty based on their brand experience. In addition, prior researches tend to disregard the complexities of brand experience and brand loyalty by treating them as a single construct (Brakus et al, 2009; Ding \& Tseng, 2015; Olsen et al, 2013; StokburgerSauer et al, 2012). This might rule out their distinct but significant dimensions. This research is replicating the previous work and tests their specific dimensions, namely, brand experience that 
Jurnal Bisnis dan Manajemen, Volume 20, No. 2, September 2019, p. 91-107

consists of sensory, intellectual, and behavioral experience and brand loyalty that consists of behavioral and attitudinal loyalty. Hence, this research should offer a more detailed examination of the dimensions of both brand experience and brand loyalty than previous studies. Not only that, to address these critical research questions, this research is using the same model that was proposed by Huang (2017) that is stimulated by brand experiences (sensory, intellectual, and behavioural experience), through brand love and brand trust, and ended with an outcome of brand loyalty (behavioural and attitudinal loyalty).

\section{LITERATURE REVIEW}

Brand experience, as conceptualized by Brakus et al. (2009), is concerned with subjective responses to consumers internally. These behavioral responses are generated by brand-related stimuli that are part of factors such as brand design and identity, packaging, communication, and the environment. Brand experience has strength and intensity. In other words, consumers will feel the brand experience is stronger or stronger than other consumers. The experience of the brand is related to the experience of products and services, where also the experience of the brand is different in valence. Some are more positive than others, and some experiences maybe even harmful. Furthermore, some brand experiences occur spontaneously and quickly, while others will experience intentionally and for longer. Over time, this long-lasting brand experience that is stored in consumers' memories and will then influence the consumer.

Experience occurs in many activities carried out by consumers, such as when consumers search for products, or when they shop, when they receive services, and when they consume them. Specifically, the experience of consumption is the multidimensional construct, which includes hedonic dimensions. Examples of hedonic dimensions are feeling, fantasy, pleasure, and others.

Sensory experience is the sensation responses of consumers that rose by brand-related stimuli, which is an element of the design and brand identity, packaging, communication and the environment (Brakus et al, 2009). Humans have five senses that are used to experience a brand. The most powerful sense is sight. It can find changes and differences in the environment which can also as the most common sense in understanding goods or services. The second sense is the sense of sound that is related to emotion and feelings when the consumers heard about the brand. The third sense is sense of smell that is related to pleasure and wellbeing and is closely connected to emotions and memories. The fourth sense is the sense of taste is the most distinct emotional sense and often interacts with other senses. In the final sense, the sense of touch is the tactile one. It is related to information and feelings about a product through physical and psychological interactions (Hultén, 2011).

Intellectual experience is the response of consumer cognition caused by brand-related 
Jurnal Bisnis dan Manajemen, Volume 20, No. 2, September 2019, p. 91-107

stimuli. These stimuli relate to design, identity, packaging, communication, brand environment, and other things (Brakus et al, 2009). Intellectual experience is usually experienced by consumers when they encounter a new type of product that they have never seen or heard before. Since companies keep inventing new products for the market, consumers are also using their cognition to learn about the new product. For example, in this research, the Samsung smartphone keeps inventing new versions every year with new features that are new for the users. When the users buy the new smartphone they must learn about the new feature and thus gain knowledge about the new technology that Samsung offers.

Intellectual experiences also engage consumers intellectually by appealing them in a cognitive and creative way. Intellectual campaigns are engaging as they often have collaborative elements like co-creating products or ideas together with the brand (Mohd-Ramly \& Omar, 2017). Intellectual experience is usually found in technological products, but they can be experienced in fashion and retail as well.

Behavioral experience is behavioral responses of consumers rose by brand-related stimuli that are part of a brand's design and identity, packaging, communications, and environment (Brakus et al., 2009). Behavioral experiences appeal to customers by targeting their physical experiences and showing them alternative ways of doing things by appealing to their lifestyles and interactions. Behavioral and lifestyle changes are motivated by emotions and inspiration. Using celebrities in marketing campaigns can stimulate the act experience. For example, in this research, Samsung smartphone can help the users to work out by using the Samsung Health application.

Brand love is a passionate affection that consumers have towards a brand. Brand love is an essential element in consumer-brand relationships (Bagozzi et al, 2017; Hegner et al, 2017; Langner et al, 2016; Sarkar, 2014). Furthermore, brand love is also known as a sharp construct (Barker et al, 2015). In other words, consumers are able to form "love" relationships with brands in different categories of products (Fetscherin et al, 2014).

Brand love can grow, which is based on experience with brands. Another way is through controlled (company-sponsored) or uncontrolled (word of mouth) communication about a brand. For instance, a consumer can feel like or yearn for a brand without having an opportunity to experience it at all. Furthermore, individual personality influences the development of brand love. For example, consumers who view a brand in accordance with the consumer's self-concept, they are easier to develop brand love for the brand.

In Delgado (2011), brand trust is defined as the feeling of security that consumers have in their interactions with brands. Furthermore, trust is based on consumers' perception that a brand is not only reliable but also responsible for the interests and welfare of consumers. This definition explains that brand love involves a desire to put oneself at risk, both by relying on the promise of value represented by the brand. Not only that, brand trust is defined by feelings of confidence and security. 
Jurnal Bisnis dan Manajemen, Volume 20, No. 2, September 2019, p. 91-107

Then, brand trust involves general expectations because trust cannot exist without the possibility of error. Also, brand trust is related to positive or nonnegative outcomes. Finally, brand trust is closely related to the attribution of disposition to the brand in such a way. Thus, the brand is considered reliable, reliable, and others.

In correspondence with the literature review of Delgado's research, the definition of brand trust also incorporates all essential facets of trust that researchers include in their operationalization, such as beliefs about reliability and intentionality. The reliability dimension of brand trust has a technical nature because it involves the perception that the brand can fulfill or satisfy consumers' needs. This is related to the individual's belief that the brand fulfills its promise of value. Delgado believes that this dimension is necessary for putting trust in a brand because if consumers consider brand as the promise of future performances, its reliability for the accomplishment of that promise guides the consumer to trust in the occurrence of future satisfaction. Underlying this dimension is there is a sense of predictability that the brand satisfies the individual's needs in consistently positive ways. Therefore, reliability is acknowledged as a starting point to be able to describe the brand's trust in all its values in conducting daily exchanges.

The second dimension, intentionality, portrays emotional security on the part of individuals. This dimension illustrates aspects of belief that go beyond the available evidence to make individuals feel confident that the brand will be responsible and concerned regardless of changing situations and future problems with product consumption. Confidence in these qualities is held and followed by the hopeful belief that future events will prove that they are true. Therefore, intentionality dimension is focused on the belief that the brand is not going to take advantage of the consumers' vulnerability.

Summarily, both dimensions of brand trust show different perspectives from which making subjective probability judgments for a brand to be considered trustworthy. The dimensions arise out of different levels of cognitive and emotional abstraction and allow consumers to know what precisely a trustworthy brand is.

Brand loyalty is defined as a commitment to buy back the preferred product. Commitment is carried out consistently and also has an impact on repeat purchases of the same brand. This commitment does not depend on the influence of the situation on consumers and ways of marketing that will influence to cause switching behavior (Oliver 1999 in Kabiraj \& Shanmugan, 2010). This definition promotes the two different aspects of brand loyalty. Those two aspects are behavioral loyalty and attitudinal loyalty.

According to Limpasirisuwan and Donkwa (2017), brand loyalty is a crucial and salient factor that indicates a company's performance. Brand loyalty can become a competitive advantage for a company in the market since it can be assessed in terms of both behavior and attitude. The concept of brand loyalty is increasingly adopting an 
Jurnal Bisnis dan Manajemen, Volume 20, No. 2, September 2019, p. 91-107

integrative approach to model the antecedents to brand loyalty.

Behavioural loyalty is repeated purchase of a particular product or service, evaluated either by the sequence in which it is purchased, by the proportion of purchases, by the act of recommendation, by the scale of the relationship, by its scope, or both, or by several of these criteria combined (Bodet, 2008). Behavioral loyalty has been a popular topic in both business and consumer marketing. The concept of behavioral loyalty lies in the fact that consumers are repurchasing the same brand out of habit or convenience without thinking much about it, no matter whether they like it or not (Kang, 2015).

Attitude loyalty is defined as the psychological commitment of consumers to a brand and their belief that the brand is different from others (Chaudhuri \& Holbrook, 2001 in Huang, 2017). Attitudinal loyalty is considered to be a key component in understanding a large loyalty structure by incorporating psychosocial attachment as a distinguishing factor of loyalty concept. The attitude dimension is vital in defining loyalty. Specifically, this dimension states that to show brand loyalty implies repeated purchases based on cognitive, affective, evaluative, and conative factors. These three components are the main dimensions of attitude (Kang, 2015).

Brand experience in this research consists of three elements, sensory, intellect, and behavior. Sensory experience and intellect experience are cognitive responses while behavior experience is a behavioral response. Following the fundamental of the hierarchy of the effects, cognition-affectionbehavior model, consumers' cognitive responses (sensory experience and intellectual experience), and their behavioral responses (behavior experience) might raise their emotions (e.g. brand love) (Solomon, 2015). There are also related studies that demonstrate the significant effect of brand experience on brand love (Ferreira et al, 2017; Huang, 2017; Sarkar, 2011; Bıçakcıŏlu \& Bayraktaroğlu, 2018; Yang et al, 2018; Ding \& Tseng, 2015; Iglesias et al, 2011; Ramaseshan \& Stein, 2014; Francisco-Maffezzolli et al, 2014; Yoon \& Youn, 2016).

Sensory and intellectual experiences are described as consumers' cognitive responses, such as touching, seeing, and knowing; these two experiences thus have cognitive elements. There are some works of literature that are related to this research that has demonstrated the significant antecedents of brand trust, such as functional benefit, actual uses, and satisfaction (Laroche et al., 2012). Because these antecedents have cognitive elements, sensory experience, and intellectual experience, sharing similar elements, might have their effect on brand trust. Behavioral experience, conceptualized as the behavioral interactions and participations with the brands, following the hierarchy effects, behavioural-cognition-affection sequence, might have its effect on cognitive responses, such as brand trust (Solomon, 2015). There are also related studies that demonstrate the significant effect of brand experience on brand trust (Sahin et al, 2011; Chinomona, 2013; Huang 2017; Başer et al, 2015; Ong \& Zien, 2015; Riasma et al, 
Jurnal Bisnis dan Manajemen, Volume 20, No. 2, September 2019, p. 91-107

2018; Kang, et al 2017; Ong \& Zien, 2015; Hariyanto, 2018; Wardani \& Gustia, 2017).

Emotions shape brand love. Specifically, emotions such as passion, positive attitude and evaluation, liking, attachment, commitment, and others form brand love (Albert et al., 2008; Batra et al., 2012). Thus, it can be said that brand love has an emotional component. In other words, if consumers like a brand, then they might have greater brand loyalty. Not only that, they have the desire to use, and also the willingness to invest more resources in buying the brand. This is called faithful behavior to be more involved, and to spread positive word of mouth (WOM), and have a positive attitude (Batra et al., 2012). There are also related studies that show the significant effects of this emotional component, for example, attachment on brand loyalty (Konadu, 2018; Bozbay et al, 2018; Bairrada et al, 2018; Huang 2017; Ferreira et al, 2017; Drennan et al, 2015; Fuchs et al., 2015; Bergkvist \& Bech-Larsen, 2010).

Brand trust is related to consumers' perceptions of a brand where the brand is reliable and also has an impact on their lives. This is said to be a cognitive element of trust (Delgado-Ballester, 2011). From a conceptual point of view, if consumers feel a sense of security, that is, believe in a brand, they might buy it in the near future or they have purchase intentions and also behavioral loyalty. Not only behavioral loyalty, customer attitude loyalty must also develop over time, when their trust in a brand builds up. Related studies also show the effect of brand trust on brand loyalty (Hur et al., 2014; La and Choi, 2012; Sahin et al, 2011;
Chinomona \& Dubihlela, 2014; Vazifehdoost et al, 2014; Huang, 2017; Choi \& La, 2013; Lee et al, 2015; Gecti \& Zengin, 2013; Hanzaee \& Andervazh, 2012).

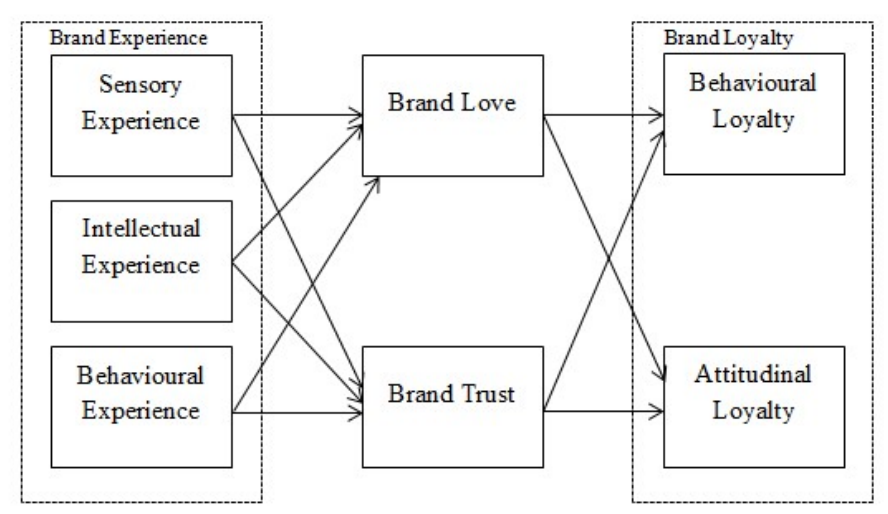

Figure 1. Conceptual Framework

Source: Huang (2017)

Figure 1 shows the research model and hypothesis in this study can be stated as follows:

H1a: Sensory experience has a positive effect on brand love.

H1b: Intellectual experience has a positive effect on brand love.

H1c: Behavioural experience has a positive effect on brand love.

H2a: Sensory experience has a positive effect on brand trust.

$\mathrm{H} 2 \mathrm{~b}$ : Intellectual experience has a positive effect on brand trust.

$\mathrm{H} 2 \mathrm{c}$ : Behavioural experience has a positive effect on brand trust.

H3a: Brand love has a positive effect on behavioral loyalty.

H3b: Brand love has a positive effect on attitudinal loyalty. 
Jurnal Bisnis dan Manajemen, Volume 20, No. 2, September 2019, p. 91-107

H4a: Brand trust has a positive effect on behavioural loyalty.

H4b: Brand trust has a positive effect on attitudinal loyalty.

\section{METHODS}

The type of this study is a descriptive study. Descriptive study is describing the characteristics of objects, people, groups, organizations, or environment. Descriptive research tries to "paint a picture" of a given situation (Zikmund \& Babin 2010, p.45). Descriptive studies are invariably conducted in non-contrived settings or usually called field studies (Sekaran \& Bougie 2016, p.100). The survey method was applied to collect relevant data for this study.

The population of this study was Samsung Smartphone users in Indonesia. The sample size was determined by using a sample size similar to previous studies that specify the right variables (Zikmund \& Babin 2010:346). Based on the previous similar researches (e.g., Forsido, 2012; Dagger \& David, 2012; Ghafoor et al., 2012; Ahmed \& Moosavi, 2013; Barnes et al., 2014; Ding \& Tseng, 2015; Alhaddad, A. (2015); Huang, 2017; El Naggar \& Bendary, 2017; Sheeraz et al., 2018), the researcher planned for 330 samples size applied in this research. Specifically, design sampling for this research is using judgemental sampling. Data was collected through personally administered questionnaires and online questionnaires. With personally administered questionnaires, respondents can ask any questions that can be clarified on the spot and the researcher can collect responses in a short time. Online questionnaires can be distributed for respondents that are not in the same area as the researcher easily and quickly. The researcher only needs to share the questionnaire link to the respondents. Moreover, most online questionnaires store answers from the respondents in the form of tables and graphs make analyzing data easier for the researcher (Sekaran \& Bougie 2016, p.143).

The measurement scale that is used for this study is the interval scale. The type of this scale is five-point Likert Scale. The statistical test for this study is using Structural Equation Modelling (SEM). However, before proceeding with SEM, a pre-test was conducted, and the data were tested its reliability and validity to ensure that the variables and indicators used in this research are reliable and valid. The researcher was using PLS-SEM to analyze the data (Hair et al, 2011) and used SmartPLS 3.0 as the data analysis software package. Furthermore, the researcher is using t-test and $\mathrm{p}$-value for hypothesis testing.

\section{RESULTS AND DISCUSSION}

From 330 questionnaires that were returned by the respondents, 300 of them can be used for data analysis. From 300 questionnaires, there are some categories that are used in this research to classify the respondents. Those categories are based on gender, age, frequency of buying Samsung smartphones, the length of time of Samsung smartphone usage, and the amount of money that was spent on buying a Samsung smartphone. Table 
Jurnal Bisnis dan Manajemen, Volume 20, No. 2, September 2019, p. 91-107

2 is showing the profile of the respondents for this research.

Table 2. Respondent Profile

\begin{tabular}{|c|c|c|c|}
\hline $\begin{array}{l}\text { Demographic } \\
\text { Variables } \\
\end{array}$ & Categories & Total & Percentage $(\%)$ \\
\hline \multirow[t]{2}{*}{ Gender } & Male & 133 & 44.3 \\
\hline & Female & 167 & 55.7 \\
\hline \multirow[t]{4}{*}{ Age } & $18-21$ years old & 125 & 41.7 \\
\hline & $22-30$ years old & 92 & 30.7 \\
\hline & $31-40$ years old & 38 & 12.7 \\
\hline & $41-50$ years old & 45 & 15.0 \\
\hline \multirow{4}{*}{$\begin{array}{l}\text { Samsung } \\
\text { smartphones } \\
\text { purchase } \\
\text { frequency }\end{array}$} & Once a year & 25 & 8.3 \\
\hline & Once per 2 years & 70 & 23.3 \\
\hline & Once per 3 years & 53 & 17.7 \\
\hline & $\begin{array}{l}\text { More than once } \\
\text { per three years }\end{array}$ & 152 & 50.7 \\
\hline \multirow{4}{*}{$\begin{array}{l}\text { The length of time } \\
\text { of Samsung } \\
\text { smartphone usage }\end{array}$} & A year & 48 & 16.0 \\
\hline & 2 years & 73 & 24.3 \\
\hline & 3 years & 64 & 21.3 \\
\hline & $\begin{array}{l}\text { More than three } \\
\text { years }\end{array}$ & 115 & 38.3 \\
\hline \multirow{3}{*}{$\begin{array}{l}\text { The amount of } \\
\text { money that were } \\
\text { spent to buy a } \\
\text { Samsung } \\
\text { smartphone }\end{array}$} & $\begin{array}{l}\text { Rp 1,000,001 - } \\
\text { Rp 3,000,000 }\end{array}$ & 86 & 28.7 \\
\hline & Rp 3,000,001 - & 86 & 28.7 \\
\hline & $\operatorname{Rp} 5,000,000$ & & \\
\hline
\end{tabular}

Source: Processed data (2018)

The following shows the results of the PLS Measurement Outer Model for the variables Brand Experience (Sensory Experience, Intellectual Experience, and Behavioral Experience), Brand Love, Brand Trust, and Brand Loyalty (Behavioral Loyalty and Attitudinal Loyalty). The model consists of the reliability test, which is seen from the Cronbach Alpha value, validity test, which is testing the outer loading value, and correlation test that Fornell-Lacker criterion. Table 3 shows the Cronbach's Alpha value of each variable. The requirement value of Cronbach's Alpha is $\geq 0.700$. Based on the table, all the variables have met the requirement value.

Table 3. Reliability Test

\begin{tabular}{lccc}
\hline Variables & $\begin{array}{c}\text { Cronbach's } \\
\text { alpha } \\
\text { Coefficient }\end{array}$ & AVE & CR \\
\hline $\begin{array}{l}\text { Sensory } \\
\text { Experience }\end{array}$ & 0.741 & 0.793 & 0.885 \\
$\begin{array}{l}\text { Intellectual } \\
\text { Experience }\end{array}$ & 0.840 & 0.758 & 0.904 \\
$\begin{array}{l}\text { Behavioral } \\
\text { Experience }\end{array}$ & 0.753 & 0.800 & 0.889 \\
$\begin{array}{l}\text { Brand Love } \\
\text { Brand Trust }\end{array}$ & 0.948 & 0.798 & 0.960 \\
$\begin{array}{l}\text { Behavioral } \\
\text { Loyalty }\end{array}$ & 0.865 & 0.713 & 0.908 \\
$\begin{array}{l}\text { Attitudinal } \\
\text { Loyalty }\end{array}$ & 0.804 & 0.633 & 0.874 \\
\hline
\end{tabular}

Source: Processed data (2018)

Table 4 shows that the value of outer loadings of all valid indicators. The requirement value of outer loading so the indicator can be called valid is above 0.700 . Furthermore, Table 5 shows the result of the correlation test of each variable. The value of each variable with its construct must be higher than other constructs. 
Jurnal Bisnis dan Manajemen, Volume 20, No. 2, September 2019, p. 91-107

Table 4. Validity Test

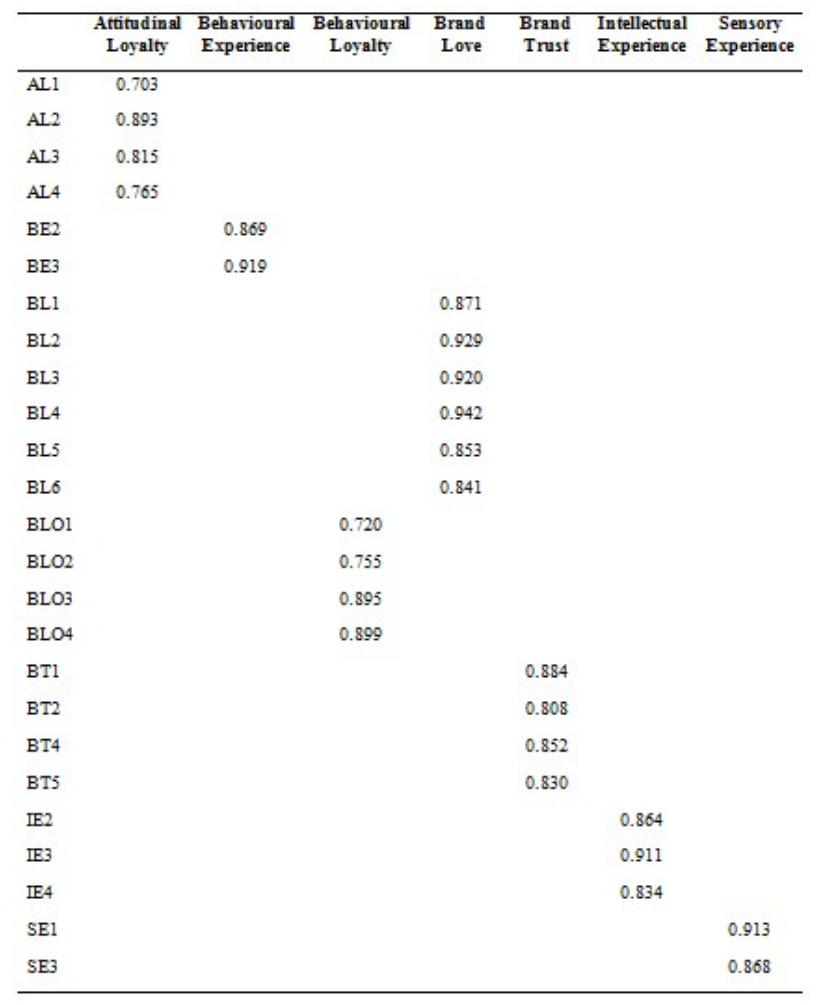

Source: Processed data (2018)

Discriminant validity testing can be done by a correlation test. Table 5 shows the result of correlation testing by applying the Fornell-Lacker criterion. This method compares the square root of the average variance extracted (AVE) with the correlation of latent constructs. A latent construct should explain better the variance of its indicator rather than the variance of other latent constructs. Therefore, the square root of each construct's AVE should have a higher value than the correlations with other latent constructs.
Table 5. Correlation Test

\begin{tabular}{lccccccc}
\hline Variables & $\begin{array}{c}\text { Sensory } \\
\text { Experience }\end{array}$ & $\begin{array}{c}\text { Intellectual } \\
\text { Experience }\end{array}$ & $\begin{array}{c}\text { Behavioural } \\
\text { Experience }\end{array}$ & $\begin{array}{c}\text { Brand } \\
\text { Love }\end{array}$ & $\begin{array}{c}\text { Brand } \\
\text { Trust }\end{array}$ & $\begin{array}{c}\text { Behavioural } \\
\text { Loyalty }\end{array}$ & $\begin{array}{c}\text { Attitudinal } \\
\text { Loyalty }\end{array}$ \\
$\begin{array}{l}\text { Sensory } \\
\text { Experience }\end{array}$ & $\mathbf{0 . 8 9 0}$ & & & & & & \\
$\begin{array}{l}\text { Intellectual } \\
\text { Experience }\end{array}$ & 0.569 & $\mathbf{0 . 8 7 7}$ & & & & & \\
$\begin{array}{l}\text { Behavioural } \\
\text { Experience }\end{array}$ & 0.450 & 0.595 & $\mathbf{0 . 8 9 5}$ & & & & \\
Brand Love & 0.610 & 0.720 & 0.586 & $\mathbf{0 . 8 9 3}$ & & & \\
Brand Trust & 0.490 & 0.471 & 0.560 & 0.731 & $\mathbf{0 . 8 5 4}$ & & \\
$\begin{array}{l}\text { Behavioural } \\
\text { Loyalty }\end{array}$ & 0.623 & 0.595 & 0.523 & 0.751 & 0.664 & $\mathbf{0 . 8 2 1}$ & \\
$\begin{array}{l}\text { Attitudinal } \\
\text { Loyalty }\end{array}$ & 0.543 & 0.423 & 0.495 & 0.576 & 0.644 & 0.726 & $\mathbf{0 . 7 9 7}$ \\
\hline
\end{tabular}

Source: Processed data (2018)

From the series of outer model tests, all criteria of the outer model have been met according to the tables. After the outer model test, the next step is to do inner model analysis or hypothesis testing (Table 6).

Table 6. Hypothesis Testing

\begin{tabular}{|c|c|c|c|c|}
\hline & & $\begin{array}{c}\mathbf{T} \\
\text { Statistics }\end{array}$ & $\begin{array}{c}\text { P } \\
\text { Values } \\
\end{array}$ & Conclusion \\
\hline H1a & $\begin{array}{l}\text { Sensory } \\
\text { Experience } \\
\text {-> Brand } \\
\text { Love }\end{array}$ & 5.431 & 0.000 & Supported \\
\hline $\mathrm{H} 1 \mathrm{~b}$ & $\begin{array}{l}\text { Intellectual } \\
\text { Experience } \\
\text {-> Brand } \\
\text { Love }\end{array}$ & 8.662 & 0.000 & Supported \\
\hline $\mathrm{H} 1 \mathrm{c}$ & $\begin{array}{l}\text { Behavioral } \\
\text { Experience } \\
\text {-> Brand } \\
\text { Love }\end{array}$ & 4.696 & 0.000 & Supported \\
\hline $\mathrm{H} 2 \mathrm{a}$ & $\begin{array}{l}\text { Sensory } \\
\text { Experience } \\
\text {-> Brand } \\
\text { Trust }\end{array}$ & 4.624 & 0.000 & Supported \\
\hline $\mathrm{H} 2 \mathrm{~b}$ & $\begin{array}{l}\text { Intellectual } \\
\text { Experience } \\
\text {-> Brand } \\
\text { Trust }\end{array}$ & 1.624 & 0.105 & Unsupported \\
\hline $\mathrm{H} 2 \mathrm{c}$ & $\begin{array}{l}\text { Behavioral } \\
\text { Experience } \\
\text {-> Brand } \\
\text { Trust }\end{array}$ & 4.972 & 0.000 & Supported \\
\hline $\mathrm{H} 3 \mathrm{a}$ & $\begin{array}{l}\text { Brand Love } \\
->\end{array}$ & 10.644 & 0.000 & Supported \\
\hline
\end{tabular}


Jurnal Bisnis dan Manajemen, Volume 20, No. 2, September 2019, p. 91-107

\begin{tabular}{|c|c|c|c|c|}
\hline & $\begin{array}{l}\text { Behavioral } \\
\text { Loyalty }\end{array}$ & & & \\
\hline $\mathrm{H} 3 \mathrm{~b}$ & $\begin{array}{l}\text { Brand Love } \\
-> \\
\text { Attitudinal } \\
\text { Loyalty }\end{array}$ & 3.867 & 0.000 & Supportec \\
\hline $\mathrm{H} 4 \mathrm{a}$ & $\begin{array}{l}\text { Brand Trust } \\
-> \\
\text { Behavioral } \\
\text { Loyalty }\end{array}$ & 3.413 & 0.001 & Supportec \\
\hline $\mathrm{H} 4 \mathrm{~b}$ & $\begin{array}{l}\text { Brand Trust } \\
-> \\
\text { Attitudinal } \\
\text { Loyalty }\end{array}$ & 5.846 & 0.000 & Supportec \\
\hline
\end{tabular}

Based on table 6, it is shown that there are nine supported hypotheses and one unsupported hypothesis. The indication of whether the thesis is supported or not can be seen from the $t$ statics and p-value. A hypothesis can be called supported if the $\mathrm{t}$ statistic value is \pm 1.96 , and the $\mathrm{p}$-value is $\leq 0.05$. From the result, it can be seen that the unsupported hypothesis is $\mathrm{H} 2 \mathrm{~b}$.

Hypothesis $2 \mathrm{~b}$ showed that there is no positive effect between intellectual experience and brand trust. There are three reasons why this hypothesis is unsupported. The first reason is that hypothesis $2 \mathrm{~b}$ has $\mathrm{t}$ statistic value of 1.624 and $\mathrm{p}$-value of 0.105 . Because the $t$ statistic value is below \pm 1.96 and the $p$ value is above $\leq 0.05$ it is concluded that this hypothesis is unsupported. The second reason is, according to Carl and Billari (2014), intelligence and trust are supposed to be highly correlated. Seeing that the hypothesis in this study is unsupported, it can be concluded that intellectual experience and brand trust in this study is not highly correlated. The third reason is the previous research by Huang (2017) also found that there is no relation between intellectual experience and brand trust. These findings indicate that sensory experience and behavior are two important things as a foundation for brand trust. Brand trust is important in shaping customer loyalty to the brand.

The result from this research shows that there is one unsupported hypothesis out of twelve. Related to this research, there are some suggestions that can be applied to Samsung in Indonesia. Consumers who have positive brand experience will come to love Samsung smartphone. Samsung needs to increase consumers' interactions with the brand through sensory experience (e.g. seeing, hearing, and feeling), intellectual experience, and behavioral experience. To increase consumers' love for the products, Samsung needs to keep track on consumers' responds toward the brand. Samsung also needs to maintain the trust that the consumers' have towards the brand. Samsung can protect trust by giving positive brand experiences. To do so, Samsung can improve technology to give the consumers' better experience with the products.

After developing a loving relationship and trusting relationships with the consumers, Samsung can gain loyalty from the consumers. In order to do so, Samsung needs to increase the product quality and service quality according to consumers' needs. If Samsung managed to improve its smartphone technology that increases the product's usability, consumers who already love the products will become loyal to the brand. Improving the security function and consumer service will improve consumers' trust, and as time passed they will be loyal because they believe that Samsung is a safe 
brand to use. To be detailed, managerial implications per variable are shown below (Table

7).

Table 7. Managerial Implications

\begin{tabular}{|c|c|c|c|}
\hline Variable & $\begin{array}{l}\text { Prioritized } \\
\text { Indicator }\end{array}$ & Consumers' Needs & Actions that can be done by Samsung \\
\hline $\begin{array}{l}\text { Sensory } \\
\text { Experience }\end{array}$ & Comfortableness & $\begin{array}{l}\text { Consumers are } \\
\text { comfortable when they } \\
\text { hold the smart-phones for } \\
\text { a long time. }\end{array}$ & $\begin{array}{l}\text { Design smartphones that can be grasped } \\
\text { comfortably. } \\
\text { Use materials that are heat resistant and } \\
\text { can cool down the smart-phone. }\end{array}$ \\
\hline $\begin{array}{l}\text { Intellectual } \\
\text { Experience }\end{array}$ & $\begin{array}{l}\text { Increasing users' } \\
\text { knowledge }\end{array}$ & $\begin{array}{l}\text { Consumers can gain } \\
\text { knowledge through } \\
\text { smart-phone interact- } \\
\text { ions. }\end{array}$ & $\begin{array}{l}\text { Create applications that can help } \\
\text { students to access literature that are } \\
\text { used in their study. } \\
\text { Create applications that enable } \\
\text { consumers, in general, to access usable } \\
\text { information regarding science and } \\
\text { health from credible experts, not only } \\
\text { about news, finance, and politics. }\end{array}$ \\
\hline $\begin{array}{l}\text { Behavioral } \\
\text { Experience }\end{array}$ & $\begin{array}{l}\text { Communication } \\
\text { with other users }\end{array}$ & $\begin{array}{l}\text { Consumers can easily } \\
\text { communicate with other } \\
\text { users with Samsung } \\
\text { smart-phone. }\end{array}$ & $\begin{array}{l}\text { Improve the software, so there are no } \\
\text { lags when consumers are receiving calls } \\
\text { or calling others. } \\
\text { Improve the sound and camera so } \\
\text { consumers can do video calls more } \\
\text { clearly. }\end{array}$ \\
\hline $\begin{array}{l}\text { Brand } \\
\text { Love }\end{array}$ & $\begin{array}{l}\text { Attachment to } \\
\text { Samsung brand }\end{array}$ & $\begin{array}{l}\text { Consumers fell in love } \\
\text { with Samsung and feel } \\
\text { attached to the brand. }\end{array}$ & $\begin{array}{l}\text { Improve the products to be more usable } \\
\text { for consumers' daily activities and } \\
\text { entertainment. } \\
\text { Improve service quality that makes } \\
\text { consumers feel like they are being } \\
\text { listened to and being helped with their } \\
\text { problems. }\end{array}$ \\
\hline $\begin{array}{l}\text { Brand } \\
\text { Trust }\end{array}$ & $\begin{array}{l}\text { Meeting } \\
\text { consumers' } \\
\text { expectations }\end{array}$ & $\begin{array}{l}\text { Consumers feel safe with } \\
\text { the brand because the } \\
\text { products are suitable for } \\
\text { their expectations. }\end{array}$ & $\begin{array}{l}\text { Create a survey on consumers' needs in } \\
\text { order to develop products that are more } \\
\text { suitable for consumers. } \\
\text { Improve smartphone security so users } \\
\text { can safely store their personal data. } \\
\text { Create an anti-theft system. }\end{array}$ \\
\hline $\begin{array}{l}\text { Behavioral } \\
\text { Loyalty }\end{array}$ & Word of Mouth & $\begin{array}{l}\text { Consumers talk about } \\
\text { Samsung to their } \\
\text { colleagues and friends }\end{array}$ & $\begin{array}{l}\text { Enable loyal consumers to endorse the } \\
\text { product through social media. }\end{array}$ \\
\hline
\end{tabular}


Jurnal Bisnis dan Manajemen, Volume 20, No. 2, September 2019, p. 91-107

\begin{tabular}{llll}
\hline Variable & $\begin{array}{c}\text { Prioritized } \\
\text { Indicator }\end{array}$ & \multicolumn{1}{c}{ Consumers' Needs } & Actions that can be done by Samsung \\
\hline & & $\begin{array}{l}\text { and recommend } \\
\text { Samsung brand to them. }\end{array}$ & $\begin{array}{l}\text { Create giveaway events on social } \\
\text { media. }\end{array}$ \\
$\begin{array}{l}\text { Attitudinal } \\
\text { Loyalty }\end{array}$ & $\begin{array}{l}\text { Willingness to } \\
\text { Pay Premium }\end{array}$ & $\begin{array}{l}\text { Consumers are paying a } \\
\text { premium for the product. }\end{array}$ & $\begin{array}{l}\text { Improve product quality. } \\
\text { Intests about Samsung. }\end{array}$ \\
& & $\begin{array}{l}\text { Maintain the uniqueness of the product. } \\
\text { Improve technology. }\end{array}$ \\
\hline
\end{tabular}

Source: Processed data (2018)

\section{CONCLUSION}

In conclusion, this research has found that there is no positive effect of sensory experience on brand trust while there are positive effects of brand experience (sensory experience, intellectual experience, and behavioral experience) on brand love, sensory experience and behavioral experience on brand trust, brand love on brand loyalty (behavioral loyalty and attitudinal loyalty), and brand trust on brand loyalty (behavioral loyalty and attitudinal loyalty).

This study also has some limitations, such as; (1) The sample might be very weak because the samples that were taken might not represent all the Samsung smartphone users in Indonesia, (2) The research object that was chosen for this research is Samsung smartphone. Samsung is one of the most popular brands in Indonesia so it limits the capability of this research to be applied in other brands, (3) This research is conducted in Indonesia only, while other countries might have different situations and conditions from Indonesia. With the different laws and cultures for each country, the result of the research might be different.
To handle the limitations, we suggest that future researchers need to do the following. Further researchers may choose different samples than the one that is in this research. The samples can be taken from other demographics or areas so it can represent the population more. Other research objects other than Samsung smartphones and cases in other countries can be chosen. Since Indonesia has its own cultures and laws, future researches are hoped to be applicable in different situations and conditions. For example, the research can be conducted in western countries that have different laws and cultures from Indonesia.

\section{REFERENCES}

Ahmed, S., \& Moosavi, Z. (2013). Factors Influencing the Cell Phone Brand Loyalty of Swedish Generation Y. Master Theses - Maladern University Sweden. Retrieved from https://www.divaportal.org/smash/get/diva2:626233/FULLTEXT 01.pdf.

Albert, N., Merunka, D. and Valette-Florence, P. (2008), "When consumers love their brands: exploringthe concept and its dimensions", Journal of Business Research, 61(10), 10621075.

Albert, N., \& Merunka, D. (2013). The role of brand love in consumer-brand relationships. Journal of Consumer Marketing, 30(3), 258-266. 
Jurnal Bisnis dan Manajemen, Volume 20, No. 2, September 2019, p. 91-107

Albert, N., Merunka, D., \& Valette-Florence, P. (2013). Brand passion: Antecedents and consequences. Journal of Business Research, 66(7), 904-909.

Alhaddad, A. (2015). Perceived quality, brand image and brand trust as determinants of brand loyalty. Journal of Research in Business and Management, 3(4), 01-08.

Aurier, P., \& Séré de Lanauze, G. (2012). Impacts of perceived brand relationship orientation on attitudinal loyalty: An application to strong brands in the packaged goods sector. European Journal of Marketing, 46(11/12), 1602-1627.

Bagozzi, R. P., Batra, R., \& Ahuvia, A. (2017). Brand love: development and validation of a practical scale. Marketing Letters, 28(1), 1-14.

Barker, R., Peacock, J., \& Fetscherin, M. (2015). The power of brand love. International Journal of Market Research, 57(5), 669-672.

Barnes, S. J., Mattsson, J., \& Sørensen, F. (2014). Destination brand experience and visitor behavior: Testing a scale in the tourism context. Annals of Tourism Research, 48, 121139.

Bairrada, C. M., Coelho, F., \& Coelho, A. (2018). Antecedents and outcomes of brand love: utilitarian and symbolic brand qualities. European Journal of Marketing, 52(3/4), 656-682.

Başer, İ. U., Cintamür, İ. G., \& Arslan, F. M. (2015). Examining the effect of brand experience on consumer satisfaction, brand trust and brand loyalty. Marmara University Journal of Economic \& Administrative Sciences, 37(2).

Batra, R., Ahuvia, A., \& Bagozzi, R. P. (2012). Brand love. Journal of marketing, 76(2), 1-16.

Bauer, H., Heinrich, D., \& Albrecht, C. M. (2009). All you need is love: Assessing consumers' brand love. In Proceedings of the American Marketing Association summer educators conference (Vol. 15, No. 2, pp. 252-253). Chicago: American Marketing Association.

Bergkvist, L., \& Bech-Larsen, T. (2010). Two studies of consequences and actionable antecedents of brand love. Journal of brand management, 17(7), 504-518.

Bıçakcıŏglu, N., İpek, İ., \& Bayraktaroğlu, G. (2018). Antecedents and outcomes of brand love: the mediating role of brand loyalty. Journal of Marketing Communications, 24(8), 863-877.

Bloemer, J. M., \& Kasper, H. D. (1995). The complex relationship between consumer satisfaction and brand loyalty. Journal of economic psychology, 16(2), 311-329.
Bodet, G. (2008). Customer satisfaction and loyalty in service: Two concepts, four constructs, several relationships. Journal of Retailing and Consumer Services. $15.156-162$. 10.1016/j.jretconser.2007.11.004.

Bozbay, Z., Karami, A., \& Arghashi, V (2018). The Relationship between Brand Love and Brand Attitude.

Brakus, J. J., Schmitt, B. H., \& Zarantonello, L. (2009). Brand experience: what is it? How is it measured? Does it affect loyalty?. Journal of marketing, 73(3), 52-68.

Carroll, B.A., \& Ahuvia, A. (2006). Some Antecedents and Outcomes of Brand Love. Marketing Letters.

Carl, N., \& Billari, F. C. (2014). Generalized trust and intelligence in the United States. PloS one, 9(3), e91786.

Chaudhuri, A., \& Holbrook, M. B. (2001). The chain of effects from brand trust and brand affect to brand performance: the role of brand loyalty. Journal of marketing, 65(2), 81-93.

Chinomona, R. (2013). The influence of brand experience on brand satisfaction, trust and attachment in South Africa. The International Business \& Economics Research Journal (Online), 12(10), 1303.

Chinomona, R., \& Dubihlela, D. (2014). Does customer satisfaction lead to customer trust, loyalty and repurchase intention of local store brands? The case of Gauteng Province of South Africa. Mediterranean Journal of Social Sciences, 5(9), 23.

Choi, B., \& La, S. (2013). The impact of corporate social responsibility (CSR) and customer trust on the restoration of loyalty after service failure and recovery. Journal of Services Marketing, 27(3), 223-233.

Choi, Y. G., Ok, C., \& Hyun, S. S. (2011). Evaluating relationships among brand experience, brand personality, brand prestige, brand relationship quality, and brand loyalty: an empirical study of coffeehouse brands.

Dagger, T., \& David, M. (2012). Uncovering the real effect of switching costs on the satisfactionloyalty association. European Journal Of Marketing, 46(3/4), 447-468. doi: $10.1108 / 03090561211202558$

Davis-Sramek, B., Droge, C., Mentzer, J. T., \& Myers, M. B. (2009). Creating commitment and loyalty behavior among retailers: what are the roles of service quality and satisfaction?. Journal of the Academy of Marketing Science, 37(4), 440.

Delgado-Ballester, E., Munuera-Aleman, J.L. and Yague-Guillen, M.J. (2003),"Development and validationof a brand trust scale". International 
Jurnal Bisnis dan Manajemen, Volume 20, No. 2, September 2019, p. 91-107

Journal of Market Research, Vol. 45 No. 1, pp. 35-54.

Delgado-Ballester, E. (2011). Development and validation of a brand trust scale.

Ding, C. G., \& Tseng, T. H. (2015). On the relationships among brand experience, hedonic emotions, and brand equity. European Journal of Marketing, 49(7/8), 994-1015.

Douglas, S. P., \& Craig, C. S. (2007). Collaborative and iterative translation: An alternative approach to back translation. Journal of International Marketing, 15(1), 30-43.

Drennan, J., Bianchi, C., Cacho-Elizondo, S., Louriero, S., Guibert, N., \& Proud, W. (2015). Examining the role of wine brand love on brand loyalty: A multi-country comparison. International Journal of Hospitality Management, 49, 47-55.

El Naggar, R. A. A., \& Bendary, N. (2017). The Impact of Experience and Brand trust on Brand loyalty, while considering the mediating effect of brand Equity dimensions, an empirical study on mobile operator subscribers in Egypt. The Business \& Management Review, 9(2), 16-25.

Ferreira, P., Rodrigues, P., \& Rodrigues, P. (2017). What do I have to do to make you love me? Brand experience as an antecedent of brand love in a retail fashion brand.

Fetscherin, M., Boulanger, M., Gonçalves Filho, C., \& Quiroga Souki, G. (2014). The effect of product category on consumer brand relationships. Journal of Product \& Brand Management, 23(2), 78-89.

Forsido, M. Z. (2012). Brand loyalty in Smartphone.

Francisco-Maffezzolli, E. C., Semprebon, E., \& Prado, P. H. M. (2014). Construing loyalty through brand experience: The mediating role of brand relationship quality. Journal of Brand Management, 21(5), 446-458.

Fuchs, C., Schreier, M., \& Van Osselaer, S. M. (2015). The handmade effect: What's love got to do with it?. Journal of Marketing, 79(2), 98-110.

Gecti, F., \& Zengin, H. (2013). The relationship between brand trust, brand affect, attitudinal loyalty and behavioral loyalty: A field study towards sports shoe consumers in Turkey. International Journal of Marketing Studies, 5(2), 111.

Ghafoor, M. M., Iqbal, H. K., Tariq, U., \& Murtaza, F. (2012). Impact of Customer Satisfaction and Brand Image on Brand Loyalty. Progress in Business Innovation \& Technology Management, 2(2), 69-77.

Greenwald, M. (2016). The 3 Best Global Brand Experiences: Guinness, Van Cleef \& Arpels, Samsung. https://www.forbes.com/sites/michellegreenwald /2016/06/06/3-of-the-best-global-brandexperiences-guinness-van-cleef-arpelssamsung/\#4b8d94d4df30

Ha, H. Y., \& Perks, H. (2005). Effects of consumer perceptions of brand experience on the web: Brand familiarity, satisfaction and brand trust. Journal of Consumer Behaviour: An International Research Review, 4(6), 438-452.

Hair, J., Ringle, C., \& Sarstedt, M. (2011). PLS-SEM: Indeed a Silver Bullet. Journal Of Marketing Theory And Practice, 19(2), 139-152. doi: 10.2753/mtp1069-6679190202

Hanzaee, K. H., \& Andervazh, L. (2012). An analysis of some moderating variables on the value, brand trust and brand loyalty chain. Research Journal of Applied Sciences, Engineering and Technology, 4(10), 1403-1413.

Hariyanto, E. (2018). The Influence of Brand Experience Through Brand Trust and Brand Satisfaction Toward Brand Loyalty Consumer at Carl's Jr Surabaya. Petra Business and Management Review, 4(2).

Hegner, S. M., Fenko, A., \& Teravest, A. (2017). Using the theory of planned behaviour to understand brand love. Journal of Product \& Brand Management, 26(1), 26-41.

Horppu, M., Kuivalainen, O., Tarkiainen, A., \& Ellonen, H. K. (2008). Online satisfaction, trust and loyalty, and the impact of the offline parent brand. Journal of Product \& Brand Management, 17(6), 403-413.

Huang, C. C. (2017). The impacts of brand experiences on brand loyalty: mediators of brand love and trust. Management Decision, 55(5), 915-934.

Hultén, B. (2011). Sensory marketing: the multisensory brand-experience concept. European Business Review, 23(3), 256-273.

Hur, W. M., Kim, M., \& Kim, H. (2014). The role of brand trust in male customers' relationship to luxury brands. Psychological reports, 114(2), 609-624.

Iglesias, O., Singh, J. J., \& Batista-Foguet, J. M. (2011). The role of brand experience and affective commitment in determining brand loyalty. Journal of Brand Management, 18(8), 570-582.

Javadein, S. R. S., Khanlari, A., \& Estiri, M. (2008). Customer loyalty in the sport services industry: the role of service quality, customer satisfaction, commitment and trust. Journal of Human Sciences, 5(2).

Johnson, R., \& Christensen, L. (2014). Educational Research (5th ed.). Thousand Oaks: SAGE Publications. 
Jurnal Bisnis dan Manajemen, Volume 20, No. 2, September 2019, p. 91-107

Kabiraj, S., \& Shanmugan, J. (2010). Development of a conceptual framework for brand loyalty: A EuroMediterranean perspective. Journal of Brand Management, 18(4-5), 285-299.

Kandampully, J., Zhang, T., \& Bilgihan, A. (2015). Customer loyalty: a review and future directions with a special focus on the hospitality industry. International Journal of Contemporary Hospitality Management, 27(3), 379-414.

Kang, S., (2015). Dual Dimensions of Attitudinal Loyalty and Behavioral Loyalty among Hotel Customers. Journal of Tourism Research \& Hospitality.

Kang, J., Manthiou, A., Sumarjan, N., \& Tang, L. (2017). An investigation of brand experience on brand attachment, knowledge, and trust in the lodging industry. Journal of Hospitality Marketing \& Management, 26(1), 1-22.

Kim, J. W., Lee, F., \& Suh, Y. G. (2015). Satisfaction and loyalty from shopping mall experience and brand personality. Services Marketing Quarterly, 36(1), 62-76.

Konadu, A. Y. (2018). Examining the Relationship of Brand Love and Brand Loyalty to Luxury Fashion Brands in Russia.

Krishna, A. (2012). An integrative review of sensory marketing: Engaging the senses to affect perception, judgment and behavior. Journal of consumer psychology, 22(3), 332-351.

La, S., \& Choi, B. (2012). The role of customer affection and trust in loyalty rebuilding after service failure and recovery. The Service Industries Journal, 32(1), 105-125.

Langner, T., Bruns, D., Fischer, A., \& Rossiter, J. R. (2016). Falling in love with brands: a dynamic analysis of the trajectories of brand love. Marketing Letters, 27(1), 15-26.

Laroche, M., Habibi, M. R., Richard, M. O., \& Sankaranarayanan, R. (2012). The effects of social media based brand communities on brand community markers, value creation practices, brand trust and brand loyalty. Computers in Human Behavior, 28(5), 1755-1767.

Lee, Y. K., Back, K. J., \& Kim, J. Y. (2009). Family restaurant brand personality and its impact on customer's emotion, satisfaction, and brand loyalty. Journal of Hospitality \& Tourism Research, 33(3), 305-328.

Lee, D., Moon, J., Kim, Y. J., \& Mun, Y. Y. (2015). Antecedents and consequences of mobile phone usability: Linking simplicity and interactivity to satisfaction, trust, and brand loyalty. Information \& Management, 52(3), 295-304.

Limpasirisuwan, N., \& Donkwa, K. (2017). A structural equation model for enhancing online brand community loyalty. International Journal of Behavioral Science, 12(1), 95-110.

Mohd-Ramly, S., \& Omar, N. A. (2017). Exploring the influence of store attributes on customer experience and customer engagement. International Journal of Retail \& Distribution Management, 45(11), 1138-1158.

Ong, C. H., \& Zien Yusoff, R. (2015). Brand Experience, Trust Components, and Customer Loyalty: Sustainable Malaysian SME Brands Study.

Ong, C. H., \& Zien Yusoff, R. (2015). Influence of Brand Experience and Personality on Loyalty Dimensions: Evidence from Successful Malaysian SME Brands.

Ottar Olsen, S., Alina Tudoran, A., Brunsø, K., \& Verbeke, W. (2013). Extending the prevalent consumer loyalty modelling: the role of habit strength. European Journal of Marketing, 47(1/2), 303-323.

Pine, B., \& Gilmore, J. (2011). The experience economy. Harvard Business Press.

Ramaseshan, B., \& Stein, A. (2014). Connecting the dots between brand experience and brand loyalty: The mediating role of brand personality and brand relationships. Journal of Brand Management, 21(7-8), 664-683.

Riasma, D. K. P., Rahyuda, K., \& Yasa, N. N. K. (2018). The role of satisfaction and trust in mediating the relationship of brand experience and loyalty.

Roy, S., Tarafdar, M., Ragu-Nathan, T. S., \& Erica, M. (2012). The Effect of Misspecification of Reflective and Formative Constructs in Operations and Manufacturing Management Research. Electronic Journal of Business Research Methods, 10(1).

Sahin, A., Zehir, C., \& Kitapç1, H. (2011). The effects of brand experiences, trust and satisfaction on building brand loyalty; an empirical research on global brands. Procedia-Social and Behavioral Sciences, 24, 1288-1301.

Samsung. (2016). Samsung 837 Opens Its Doors in the Heart of NYC Marking the First-of-its-Kind Cultural Destination, Digital Playground and Marketing Center of Excellence. Retrieved from https://news.samsung.com/global/samsung-837opens-its-doors-in-the-heart-of-nyc-marking-thefirst-of-its-kind-cultural-destination-digitalplayground-and-marketing-center-of-excellence

Sarkar, A. (2011). Romancing with a brand: a conceptual analysis of romantic consumer-brand relationship. Management \& Marketing, 6(1), 79.

Sarkar, A. (2014). Brand love in emerging market: a qualitative investigation. Qualitative market 
Jurnal Bisnis dan Manajemen, Volume 20, No. 2, September 2019, p. 91-107

research: an international journal, 17(4), 481494.

Scotland, J. (2012). Exploring the Philosophical Underpinnings of Research: Relating Ontology and Epistemology to the Methodology and Methods of the Scientific, Interpretive, and Critical Research Paradigms. English Language Teaching, 5(9), 9-16. doi: 10.5539/elt.v5n9p9

Schmitt, B., \& Rogers, D. (2008). Handbook on Brand and Experience Management. Cheltenham: Edward Elgar Pub.

Schumacker, R., \& Lomax, R. (2010). A Beginner's Guide to Structural Equation Modeling. Routledge.

Sheeraz, M., Qadeer, F., Masood, M., \& Hameed, I. (2018). Self-Congruence Facets and Emotional Brand Attachment: The Role of Product Involvement and Product Type. Pakistan Journal of Commerce and Social Sciences, 12(2), 598616.

Singh, J. J., Iglesias, O., \& Batista-Foguet, J. M. (2012). Does having an ethical brand matter? The influence of consumer perceived ethicality on trust, affect and loyalty. Journal of Business Ethics, 111(4), 541-549.

Solomon, M.R. (2014), Consumer Behavior: Buying, Having, and Being (Vol. 10), Prentice Hall,Englewood Cliffs, NJ.

Stein, C., Morris, N.,\& Nock, N. (2012). Structural Equation Modeling.

Stokburger-Sauer, N., Ratneshwar, S., \& Sen, S. (2012). Drivers of consumer-brand identification. International journal of research in marketing, 29(4), 406-418.

Sung, Y., \& Kim, J. (2010). Effects of brand personality on brand trust and brand affect. Psychology \& Marketing, 27(7), 639-661.

Vazifehdoost, H., Rahnama, A., \& Mousavian, S. J. (2014). Evaluation of the impact of brand purchase involvement, satisfaction, experience and brand trust on loyalty to brand. Mediterranean Journal of Social Sciences, 5(20), 3054.

Wardani, D., \& Gustia, R. R. (2017). Analysis of Brand Experience, Brand Satisfaction and Brand Trust Relationship to Brand Attachment. Jurnal Ilmu Manajemen \& Ekonomika, 9(1), 59-72.

Yang, D., Lu, Y., \& Sun, Y. (2018). Factors influencing Chinese consumers' brand love: Evidence from sports brand consumption. Social Behavior and Personality: an international journal, 46(2), 301311.

Yasin, M., \& Shamim, A. (2013). Brand love: Mediating role in purchase intentions and word- of-mouth. Journal of Business and Management, 7(2), 101-109.

Yoon, D., \& Youn, S. (2016). Brand experience on the website: its mediating role between perceived interactivity and relationship quality. Journal of Interactive Advertising, 16(1), 1-15. 